\title{
ANALYSIS OF FACTORS INFLUENCING THE INTEREST OF FOREIGN TOURISTS TO REVISIT BALI
}

\author{
Bagus Putu Widanta
}

\section{Universitas Udayana}

\begin{abstract}
Bali Province is not endowed with natural resources to drive its economy, but rather relies heavily on tourism as its leading sector in achieving economic growth. Against the backdrop of Bali's heavy dependence on tourism, it is necessary to conduct an analysis on how to survive the fierce tourism competition. There are mainly four strategies for attracting investments, tourists and industries into a region, namely: image, which is a set of beliefs, ideas and expressions that a person has towards a region; attraction marketing, which is attraction of a tourist destination; infrastructure marketing, which is the availability of facilities and infrastructures that can attract people, investments and capital; and people marketing, which is a strategy to market a region by marketing the attitudes of its people: how open the local community is to foreign influences (people, investments, industries and products). This study finds that image, infrastructure marketing, attraction marketing and people marketing have positive and significant effects on the interest of foreign tourists to revisit Bali. The results of this study provide a comprehensive picture for the government and related parties in formulating tour packages to attract foreign tourists to revisit Bali.
\end{abstract}

Keywords: revisit interest, image, infrastructure, attraction and people marketing JEL Classifications : C68, F43, L52

\section{INTRODUCTION}

The tourism sector along with other sectors contribute to the development of Indonesia's economy. Development in tourism provides jobs, income opportunities, as well as bolster the developments of various infrastructures which leads to the growth of Indonesia's Gross Domestic Product. Indonesia is an archipelago with long stretches of seas and coastlines making it one of the most coveted tourist destinations in the world. As a benchmark of the development of Indonesia's tourism, below is the comparison of tourist visits in Indonesia and its neighboring countries. 
Table 1. The Development of Tourist Visits to ASEAN Countries (in Thousands)

\begin{tabular}{lrrrrr}
\hline Countries & $\mathbf{2 0 1 1}$ & $\mathbf{2 0 1 2}$ & $\mathbf{2 0 1 3}$ & $\mathbf{2 0 1 4}$ & $\mathbf{2 0 1 5}$ \\
\hline Thailand & 19,098 & 22,354 & 15,568 & 15,095 & 15,231 \\
Malaysia & 24,714 & 25,033 & 25,716 & 27,437 & 25,721 \\
Singapore & 13,171 & 14,491 & 15,568 & 15,095 & 15,231 \\
Indonesia & 7,650 & 8,044 & 8,802 & 9,435 & 10,047 \\
Vietnam & 6,014 & 6,848 & 7,572 & 7,874 & 7,944 \\
Philippines & 3,917 & 4,273 & 4,681 & 4,833 & 5,361 \\
\hline
\end{tabular}

Source: Asean data, 2017

Indonesia ranks fourth

The Indonesian tourism has position in terms of the number of been growing significantly each year foreign tourist visits compared to as can be seen from the steadily neighboring countries below growing number of tourist visits in Thailand, Malaysia, and Singapore recent years. This increasing tourist while ranks only slightly above visits consequently will have a Vietnam. This fact should serve as a significant impact on the increase of wake up call for the government and the local community's income.

related agencies to accelerate the development of Indonesian tourism going forward. 
Table 2. The Growth of Tourist Visits to Indonesia

\begin{tabular}{rrrrrr}
\hline Year & Indonesia & Growth (\%) & \multicolumn{1}{c}{ Bali } & Jakarta & Riau Islands \\
\hline 2012 & $8,044,462$ & 5.16 & $2,949,332$ & $2,125,513$ & $1,767,439$ \\
2013 & $8,802,129$ & 9.42 & $3,278,598$ & $2,313,742$ & $1,859,066$ \\
2014 & $9,435,411$ & 7.19 & $3,766,638$ & $2,319,295$ & $1,973,425$ \\
2015 & $10,406,291$ & 10.29 & $4,001,835$ & $2,377,226$ & $2,037,673$ \\
2016 & $11,519,275$ & 10.27 & $4,927,937$ & - & $1,920,232$ \\
2017 & $14,039,799$ & 21.88 & $5,697,739$ & - & $2,074,534$ \\
2018 & $15,806,191$ & 12.58 & $6,070,473$ & - & - \\
\hline
\end{tabular}

Source: Central Bureau of Statistics, 2018

The enormous potentials possessed by Indonesian tourism are inseparable from the role of Balinese tourism. As can be seen from the table above, around 40 percent of foreign tourists visiting Indonesia was contributed by tourists visiting Bali. This is inline with the statement from the Minister of Tourism Arief Yahya who stated that "Bali contributes around 40 percent of the total foreign tourist visiting Indonesia. When a travel warning is issued against Bali, its impact will not only affect Bali but also Indonesia" (Tribunnews.com, 2017). The second highest tourism potential is held by Jakarta which contributes around 30 percent, the third is the
Riau Islands (Karimun, Bintan, Batam, Tanjungpinang) around 20 percent, the fourth position is held by Yogyakarta, while Bandung is in the fifth.

In 2019, President Joko Widodo revealed that the government was targeting 20 million foreign tourist visits (merahputih.com, 2017). In order to achieve this target, the supports from various parties were crucial, including those from tourism businesses. The President through The Ministry of Tourism launched a program to create ten new "Bali"s or ten priority tourist destinations, with the emphasis on improving the performances of other destinations in 
Indonesia to replicate Bali's tourism, capable of attracting six million tourists and increasing significantly each year. Ten destinations set as the new "Bali"s will possess distinct characteristics and uniqueness and are not necessarily less attractive compared to Bali. As for now, the government has agreed to focus on accelerating the development of four destinations out of the ten new "Bali"s. The development is realized through building homestays, restaurants, souvenir shops and SME centers. These four new destinations are Lake Toba, Borobudur, Mandalika and Labuan Bajo.

Bali Province is not endowed with any natural resources such as minerals, oil and gas unlike other regions in Indonesia. To drive its economy, Bali Province relies heavily on tourism as its leading sector in achieving economic growth and development. Bali is famous for its beautiful natural landscapes, as well as its uniqueness in culture, customs, history, festivities (kite festivals, cultural festivals, beach festivals, agricultural festivals, local festivals in various cities and regencies, painting and musical festivals) and various traditional ceremonies have become the main attractions for the visiting tourists. The beautiful natural landscapes of Bali have been recognized worldwide and crowned as the best destination in the world according to TripAdvisor in 2018 above of Paris. The hospitality and friendliness of Balinese people, coupled with the safety of the island provide a greater sense of security and comfort among visitors. In addition to natural factor, the human resource factor also play an influential role in the development of Balinese tourism. Uniqueness in culture and customs, the availability of supporting tourism infrastructures, tourist destinations and attractions supported by a good promotion and marketing system are highly needed in order to increase tourist visits to Bali. The increase in tourist arrivals leads to the development of tourism and its supporting infrastructures in Bali, details of which can be seen in Table 3. 
Table 3. The Number of Balinese Tourism Businesses, 2017

\begin{tabular}{llr}
\hline No & Types of Tourism Business & Units \\
\hline 1 & Accomodation & 4,883 \\
2 & Restaurant/Diner & 2,217 \\
3 & Travel Agent & 371 \\
4 & Travel Agent Branch & 23 \\
5 & Travel Agent MICE & 9 \\
6 & Retirement Travel Bureau & 9 \\
7 & Bar & 426 \\
8 & Tourism Water Sport & 237 \\
\hline
\end{tabular}

Source: Bali Province Tourism Office, 2017

The growth of the tourism sector as a leading sector also boosts the development of other sectors, such as agriculture, manufacturing, services, manufacturing and others. Bali's enormous economic dependence on the tourism sector calls for the necessity to conduct an internal analysis of strengths and opportunities as well as weaknesses and threats of tourism in Bali (Rahyuda, 2003). Miscalculations in formulating Balinese tourism products will lead Balinese tourism to the point of stagnation. According Erawan (2003), the lack of anticipations in forms of tourism policies will trap tourism into stagnation and the possibility of the Doxey hypothesis coming into effect, which illustrates the stages of attitude changes of local people towards tourism development in their area. The first stage is the initial stage, also known as the "euphoria" stage, where tourists and investors are welcomed with enthusiasm. The next stage is "apathy" stage, where tourists are accepted as given (taken for granted), and where contact with tourists is more formal. The next stage is the annoyance stage, which is already the stagnation stage, where local people feel apprehensive 
about the tourism industry. And lastly, the final stage is the antagonism stage, where the aggravation of the local community is expressed openly, tourists are seen as nothing but trouble makers.

The changing dynamics in world markets and the increasingly intense international tourism competition requires the right strategy to maintain tourism in Bali as the most sought-after and favorable destination for many tourists. The improvement of tourist safety in Bali, image promotions (roadshow promotions, media relations, and cultural diplomacies) and product improvements (transportation, facilities and infrastructures) will provide better comfort and positive impressions for visiting tourists and boost their interests to revisit in the future.

According to Kuncoro (2014), there are four strategies that can be implemented to attract investments, people (tourists) and industries into a region; namely: image, which is a set of beliefs, ideas and expressions that a person has towards a region; attraction marketing, which is attraction of a tourist destination; infrastructure marketing, which is the availability of facilities and infrastructures that can attract people, investments and capital; and people marketing, which is a strategy to market a region by marketing the attitudes of its people, i.e. how open the local community is to foreign influences (people, investments, industries and products).

Tourists may either arrive in Bali independently or organizedly via travel agents. The purposes of their visits are either traveling, business, work or education. Those who go on a vacation or travel to Bali, in addition to recreational purposes, also aspire to experience the beauty of Bali which is famous worldwide. Bali has long been wellknown for its image as the paradise island and the island of a thousand temples, rich with various attractions, such as beautiful natural landscapes, history, shopping, cultural attractions, building monuments and statues, museums and various other attractions that lure tourists to visit Bali. The comfort in a tourism destination is not solely 
determined by its attractiveness alone, rather it must also be supported by adequate infrastructures to provide greater convenience for visiting tourists. Adequate roads and transportation, the environmental quality, safety, accommodations and restaurants, and visitor / tourist services are several important factors in increasing tourist visits to Bali. The deteriorating traffic congestion in Bali recently will adversely affect the tourism sector as well as other sectors if not solved immediately. A good waste management also needs to be prioritized to prevent further deterioration of environmental quality, since a good and clean environment provides better tourist comfort and thus prolonging their stay in Bali.

The hospitality and friendliness of Balinese people in interacting with foreigners visiting Bali has been well-known since a long time ago. The honesty of the people is based on a very famous Hindu concept "Karmapala", which is the cornerstone in people marketing to attract more tourists to visit Bali.
This provides a sense of security that is difficult to find elsewhere despite having natural beauty beyond Bali.

The image, infrastructure, attraction, and people marketing of Bali has become an invaluable asset "Taksu" that makes Bali a favorite tourism destination. This is evidenced by the enthusiasm of numerous tourists who are not satisfied with visiting Bali once, but rather choose to come multiple times (repeater). This enthusiasm or interest of tourists to revisit Bali and the influencing factors behind it is an interesting topic to study.

When compared to previous researches, this research has several improvements. 1. The research subjects in previous researches were limited to general tourist perceptions only, whereas in this study the research subjects covers the perceptions of foreign tourists regarding the factors influencing their interest to revisit Bali, 2. The research object in this study is more comprehensive and extensive, whereas in previous researches objects are narrower and limited only to one tourism destination or 
certain tourist accommodation 3 . This study regresses the relationship between foreign tourists' interest to

\section{RESEARCH METHODOLOGY}

Multiple Linear Regression Analysis is an analysis that aims to determine the effect of a variable on another variable where there are linear relationships between two or more independent variables $(\mathrm{X} 1, \mathrm{X} 2, \ldots \ldots \ldots$ $\mathrm{Xn})$ and a dependent variable $(\mathrm{Y})$. The

$Y^{\prime}=\alpha+$ image $\beta_{1}+$ infrastructure $\beta_{2}+$ attraction $\beta_{3}+$ people $\beta_{4}+$ ei

Note:

$\mathrm{Y}^{\prime}=$ the interest of foreign tourists to revisit

Image $=$ the island of the gods image in the eyes of tourists

$\begin{array}{llr}\text { Infrastructure } & = & \text { marketing } \\ \text { infrastructure vector } & \text { consisting of }\end{array}$ roads and transportation, environmental quality, accommodation facilities, restaurants, and tourist services in Bali revisit Bali and the factors that influence it.

ordinal data in this study was manipulated by upgrading it into a higher measurement scale, which is the interval scale. This was done, in addition to avoid violating the norm, also to meet the normal distribution requirement in parametric testing. The estimation model used is as shown in the following equation:
Attraction $=$ attraction vector consisting of natural beauty, history, natural tourism destinations, manmade tourism destinations, monuments and statues in Bali

People $=$ people vector consisting of friendliness, honesty, openness to tourists, quality of human resources in Bali 
The stages of the analysis are as follows:

\section{a. Model Fit Test (Goodness of} Fit)

In order to ensure unbiased prediction results, the model must be assured to be valid and does not violate the assumptions of the least squares method. For this reason, the detection or testing of classical assumptions includes: 1) normality test, 2) heteroscedasticity test.

\section{Normality Test}

The normality test aims to examine whether the residuals of the regression model constructed are normally distributed or not.

Testing steps:

1) Hypotheses formulation:
Ho: the residuals tested are distributed normally $\mathrm{H} 1$ : the residuals tested are not distributed normally

2) Determine the level of significance

3) Testing criteria:

Ho is accepted if $p$. value $\geq$ level of significance

Ho is rejected if $p$. value < level of significance

\section{Heteroscedasticity Test}

Heteroscedasticity test aims to test whether there is an inconsistency of variance of residuals in the regression model from one observation to another. A good regression model does not contain symptoms of heteroscedasticity or has a homogeneous variance. The Glejser test and the Park method are used to detect the presence of heteroscedasticity in the model.

\section{b. Test of Model Parameters}

1. Test of Simultaneous Significance (F-Test)

The F-statistics test is used to determine whether all 
independent variables included

in the model have a simultaneous influence on the dependent variable (Kuncoro, 2001: 98). If the F-statistics value is greater than the F-table, then it can be said that all independent variables simultaneously influence the dependent variable (Imam Ghozali, 2006). To test the hypotheses, the F-statistics value is used with the following criteria (Imam Ghozali, 2005):

a. Quick look: if $\mathrm{F}$ value is greater than 4 then $\mathrm{H}_{0}$ can be rejected at a 5 percent confidence level, in other words accepting the alternative hypothesis, which states that all independent variables simultaneously and significantly influence the dependent variable

b. Compare the calculated F value with the $F$ value in the table. If the calculated $\mathrm{F}$ value is greater than $\mathrm{F}$ table, then $\mathrm{H}_{0}$ is rejected and Ha is accepted.
2. Test of Significance of Individual Parameters (t-Test)

The t-test basically shows the extent of the influence of one explanatory variable individually in explaining the variation of the dependent variable (Kuncoro, 2001: 97). ttest is used to test the significance of the relationship between $\mathrm{X}$ and $\mathrm{Y}$ variables, whether the $\mathrm{X} 1$ and $\mathrm{X} 2$ variables actually affect $\mathrm{Y}$ variable individually or partially (Imam Ghozali, 2006). The method of conducting the t-test is as follows:

a. Quick look: if the degree of freedom (df) value is 20 or more and the confidence level is 5 percent, then $\mathrm{H}_{0}$ can be rejected if the $t$ value is greater than 2 (in absolute term). In other words accepting the alternative hypothesis, which states that an independent variable individually influence the dependent variable.

b. Compare $t$ value with critical values according to the table. If the calculated $t-$ 
statistics value is higher than

the $t$-table, accept the alternative

hypothesis which states that all independent

variables individually influence the dependent variable.

\section{RESULTS AND DISCUSSION}

a. Descriptive Statistics of Research Variables

1. Characteristics of Respondents by Age

Table 4. Characteristics of Respondents by Age

\begin{tabular}{cc}
\hline Age Groups & Frequency \\
\hline $17-24$ & 45 \\
$25-33$ & 30 \\
$34-41$ & 6 \\
$42-49$ & 6 \\
$50-57$ & 7 \\
$58-65$ & 5 \\
$66-73$ & 1 \\
\hline Total & 100
\end{tabular}

Source: Primary data (processed), 2019

Based on Table 4, foreign tourists visiting Bali are dominated by young tourists aging from 17 years to 33 years which is 75 percent. While older tourists, ranging in age from 58 years to 73 years, are only 6 percent. This indicates that Balinese tourism is more attractive to young tourists.

Judging from the age trend of tourists visiting Bali which is dominated by young tourists and in order to be able to capture this opportunity, innovation and creativity are required in designing tourism packages that are suitable for this age segment, without compromising tourism products that are suitable for older age groups. 
2. Characteristics of Respondents by Number of Visits to Bali

Table 5. Characteristics of Respondents by Number of Visits to Bali

\begin{tabular}{cc}
\hline Number of Visits & Number of Tourist \\
\hline 1 & 34 \\
$2-7$ & 58 \\
$8-14$ & 5 \\
$15-21$ & 2 \\
$22-28$ & 0 \\
$29-35$ & 0 \\
$36-42$ & 0 \\
$43-51$ & 0 \\
52 & 1 \\
\hline Total & 100 \\
\hline
\end{tabular}

Source: Primary data (processed), 2019

Respondents who made first foreign visits to Bali are tourists who time visits to Bali to Bali were 34 have a number of visits in the range of foreign tourists, while 76 others were $\quad 2$ to 7 visits, as many as 58 people. repeater tourists who had visited Bali There is even one respondent who has multiple times. The highest number of visited Bali up to 52 times.

3. The Sources of Information Regarding Balinese Tourism

Table 6. Sources of Information Regarding Balinese Tourism

Information Sources $\quad$ Frequency


Friends

Electronic Media

Printed Media

Internet Media

Others

Source: Primary data (processed), 2019

Most respondents received still the highest source of information information about Balinese tourism about Bali. According to Hasan (2010), attractions from friends or colleagues, word-of-mouth are compliments, as many as 63 respondents. The recommendations and customer satisfaction of visiting tourists comments regarding their experiences becomes a high priority in developing on services and products that really Balinese tourism, considering that influence their decisions or buying word-of-mouth (WOM) marketing is behaviors.

\section{The Internet Media Used to Obtain Information regarding Balinese Tourism}

Table 7. Internet Media Used to Obtain Information regarding Balinese Tourism

\begin{tabular}{lc}
\hline Internet Media & Frequency \\
\hline Facebook & 48 \\
Instagram & 68 \\
WhatsApp & 36 \\
Trip advisor & 21 \\
Line & 7 \\
Others & 1 \\
\hline
\end{tabular}

Source: Primary data (processed), 2019

The robust growth of internet media also has a positive impact on the development of Balinese tourism. From the respondents' answers in the
Table 7 above, it can be seen that 53 respondents received information about Bali from the internet media. The existence of social media makes it 
easy for tourists to obtain information about Bali. According to Van Dijk in Nasrulah (2015: 11), social media is a media platform that focuses on the existence of users who facilitate activities and collaborations. Therefore, social media can be seen as an online medium (facilitator) that enhances the relationship among users while at the same time serves as a social bond.

The selection of the right social media on the internet, attractive contents and interactions with followers in promoting Balinese tourism will lead to the increase of tourist visits. From the interview results with respondents, Instagram is the most widely used social media by foreign tourists visiting Bali, followed by Facebook and WhatsApp.

\section{b. Estimation Results}

\section{Estimation Equation Model}

The estimation results indicate that all independent variables used in the model affect the interest of foreign tourists to revisit Bali. Based on the estimation results, the following equation is obtained:

$Y^{\prime}=-0,485+0,196$ image $+0,062$ infrastructure $+0,071$ attraction $+0,299$ people + ei

Table 8. Summary of Regression Model Estimates

\begin{tabular}{|c|c|c|c|}
\hline Variables & $\begin{array}{l}\text { Coefficients } \\
\text { (B) }\end{array}$ & t-stat & Sig \\
\hline Image & 0.196 & 2.088 & 0,039 \\
\hline Infrastructure Marketing & 0.062 & 2.016 & 0,047 \\
\hline Atraction Marketing & 0.071 & 2.431 & 0,017 \\
\hline People marketing & 0.299 & 4.185 & 0,000 \\
\hline $\mathbf{R}^{2}$ & df & & $\mathbf{F}$ \\
\hline 0,430 & 95 & & 17.910 \\
\hline $\begin{array}{l}\text { 2. Coefficient of D } \\
\text { Value }\end{array}$ & zation & e coe & $\begin{array}{l}\text { it of determir } \\
\text { ure the perce }\end{array}$ \\
\hline
\end{tabular}


variation of dependent variable in a multiple linear regression model can be explained by independent variables (Priyatno, 2008). From Table 8 , it can be seen that the coefficient of determination $\left(R^{2}\right)$ is 0.430 which means that 43 percent of the interest of foreign tourists to revisit Bali can be explained by independent variables in the model ( $\mathrm{X}$ variables), while the remaining 67 percent can be explained by other variables outside the model.

\section{Tests of Model Parameters}

\subsection{Simultaneous Significance Test (F-test)}

The F-statistics test is used to determine the effect of all the independent variables $(X)$ included in the model in simultaneously influencing the interest of foreign tourists to revisit Bali (Y). It can be seen from Table 8 that the calculated $F$ value of 17.910 is greater than F-table of 3.17 which means that $\mathrm{H}_{0}$ can be rejected at 5 percent confidence level. In other words, an alternative hypothesis is accepted, which states that all independent variables; image, infrastructure marketing, attraction marketing and people marketing simultaneously and significantly affect the interest of foreign tourists to revisit Bali.

\subsection{Test of Individual Parameter's Significance (t- Test)}

The t-test was conducted to test the significance of the relationship between an independent variable $(\mathrm{X})$ and a dependent variable $(\mathrm{Y})$, to determine whether $\mathrm{X} 1, \mathrm{X} 2, \mathrm{X} 3, \mathrm{X} 4$ and $X 5$ variables individually or partially affect Y (Imam Ghozali, 2006). t-test indicates the extent of influence of each independent variable; image, infrastructure marketing, attraction marketing and people marketing partially and significantly on the interest of foreign tourists to revisit Bali. It can be seen immediately from Table 8 that the significance levels in this study are all under 0.05 at 5 percent confidence level, thus $\mathrm{H}_{0}$ can be rejected. In other words the alternative hypotheses are accepted, which state that all independent variables; image, infrastructure 
marketing, attraction marketing and people marketing partially and significantly affect the dependent variables which is the interest of foreign tourists to revisit Bali.

In this study, all significance values fall below 0.05 (5 percent), namely; image with a significance value of 0.039, infrastructure marketing with a significance value of 0.047 , attraction marketing with a significance value of 0.017 and people marketing with a significance value of 0.000 .

\section{DISCUSSION}

a. THE DESCRIPTION OF BALINESE TOURISM

Balinese tourism is famous worldwide for its wide variety of tourist attractions that have drawn many foreign tourists over the years. Bali is one of the islands in the Indonesian archipelago and geographically lies between Java and Lombok islands. The majority of its inhabitants are Hindu which offers uniquenesses to their arts, culture and customs, making Bali a culture-based tourism destination.
For Australian, Japanese and other foreign tourists alike, Bali is known as Island of the Gods and Island of a Thousand Temples.

Bali is one of the favorite tourism destinations famous all over the world for its tropical natural beauty and various tourism activities available to be enjoyed by tourists. Bali possesses beautiful coastlines, charming lake views, mountains, hills, valleys and attractive rice fields. Various tourism activities and products are offered for tourists ranging from sightseeing, culinary, wedding organizer, hiking, water sports, diving, surf school to night lives such as bars and night clubs.

\section{b. THE DEVELOPMENT OF TOURISM IN BALI}

Balinese tourism was developed for the first time since the arrival of the Dutch sailors on the island of Bali in 1597 led by their ship captain, Cornelius Houtman. When Dutch ships intended to leave Bali, many of the ship's crews were reluctant to leave Bali because they were too fascinated by the 
prosperity, art and culture of the

Balinese people.

The lasting image of Bali as paradise island began in 1920 after several foreign journalists wrote articles about Bali. One of them is an American journalist who wrote a book called The Last Paradise. The moniker triggered tourists to start visiting and arriving in Bali. (tatkala.com, 2017).

Balinese pre-independence tourism began in Ubud Village Gianyar Regency in 1930, where many foreign artists chose to settle in the area. Tourism continued to develop well after the independence in 1963, marked by the establishment of the Bali Beach Hotel by President Sukarno on Sanur Beach Denpasar City as the center of tourism development in the surrounding area.
In the 1970s - 1980s, Balinese tourism began to expand, the Balinese population began to be aware of the existence of tourism, marked by the construction of infrastructures and the emergence of traditional accommodations (pensions and inns) around Kuta, Sanur and Legian. These traditional tourism accommodations are developing along with the rapid growth of Balinese tourism.

Balinese tourism grew rapidly in the 1990s. This is indicated by the number of lodging rooms in Bali that grew rapidly from 8,000 rooms in 1980 to 20,000 rooms in 1990 and grew even more to 30,000 rooms in 1997, a stark contrast from a mere 500 rooms in 1970 (BPS, 2017). 
Table 9. The Number of Hotel Rooms in Bali Province 1970-2017

\begin{tabular}{|c|c|c|c|}
\hline Year & Number of Rooms & Year & Number of Rooms \\
\hline 1970 & 500 & 2000 & 29,892 \\
\hline 1981 & 2,451 & 2001 & 29,925 \\
\hline 1982 & 2,596 & 2002 & 28,637 \\
\hline 1983 & 3,039 & 2003 & - \\
\hline 1984 & 3,063 & 2004 & 28,641 \\
\hline 1985 & 3,065 & 2005 & 31,678 \\
\hline 1986 & 4,015 & 2006 & 31,566 \\
\hline 1987 & 4,712 & 2007 & 30,175 \\
\hline 1988 & 4,814 & 2008 & 33,178 \\
\hline 1989 & 4,961 & 2009 & 29,346 \\
\hline 1990 & 5,604 & 2010 & 32,892 \\
\hline 1991 & 5,604 & 2011 & 33,911 \\
\hline 1992 & 5,604 & 2012 & 36,837 \\
\hline 1993 & 10,897 & 2013 & 38,173 \\
\hline 1994 & 13,945 & 2014 & 42,872 \\
\hline 1995 & 14,268 & 2015 & 44,657 \\
\hline 1996 & 13,938 & 2016 & - \\
\hline 1997 & 14,625 & 2017 & 94,222 \\
\hline 1998 & 16,371 & 2018 & 78,801 \\
\hline
\end{tabular}


1999 22,254

Source: BPS of Bali Province (2017)

In 2004, Balinese tourism experienced a significant downturn in term of tourist visits. This was caused by the bombing by terrorists known as the Bali Bombing 1 in 2002 and the Bali bombing 2 in 2004 .

In 2017 Bali was awarded as the best destination in the world, defeating 24 other tourism destinations. Bali island in Indonesia has become a favorite destination for tourists looking for relaxation and adventures (TripAdvisor, 2017).

c. Analysis of the Factors Influencing the Interest of Foreign Tourists to Revisit to Bali

\section{The Influence of Balinese} Tourism's Image on the Interest of Foreign Tourists to Revisit Bali

Image is a set of beliefs, ideas and expressions held by a person regarding a region (Kuncoro, 2014). Image is an implication of a lot of information related to a region. For example, people recognize Pattaya as a center for prostitutions in Thailand, the image of Ponorogo with its Reog dance, Madura with its bull racing and Irian Jaya with the Koteka. To communicate the image of an area, several methods can be used: slogans, image positioning and visual symbols.

Bali has had an image as paradise island since 1936 after several foreign journalists wrote about Bali in the media. One of them is an American writer named Hickman Powell who wrote a book called Bali: The Last Paradise. The moniker caused tourists to start visiting and come to Bali Island (Powell, 1936). Other than having the image as Paradise Island, Bali is also known as Island of the Gods and Island of a Thousand Temples.

The regression results of the study indicate that Bali's image had a positive and significant influence on the interest of foreign tourists to revisit Bali. 
Table 10. The Image of Bali

\begin{tabular}{lll}
\hline No & Statements & Score \\
\hline 1 & Bali is The Island of Gods & 402 \\
2 & Bali is famous as The Island of a Thousand Temples & 419 \\
3 & Bali is The Paradise Island & 448 \\
\hline
\end{tabular}

Source: Data processed, 2019

The results obtained from

marketing. The availability of interviews with foreign tourists visiting Bali, as shown in Table 10 sufficient infrastructures is a major consideration for tourists when indicates that in tourist's point of view Bali is best known as the Paradise Island as can be seen from the highest score obtained compared to other images. As stated by a tourist from France about his opinion on the most interesting and memorable thing in Bali (Sylvie, 2019):

"Paradise island is a very memorable and interesting place"

\section{The Inflence of Infrastructure} Marketing on the Interest of Foreign Tourists to Revisit Bali

The t-test result indicates that infrastructure marketing partially has a positive and significant effect on the interest of foreign tourists to revisit Bali. Infrastructure is one of the bases for Balinese tourism visiting Bali. The availability of supporting infrastructures for Bali tourism includes: restaurant facilities, shopping centers, hotels, transportation and roads, parking areas, meeting facilities and others.

The result of this study is in line with the research conducted by Blazeska (2018) which found that there is a significant influence of tourist infrastructure on the satisfaction of tourists visiting Ohrid. Khadaroo (2007) investigated the effect of transport infrastructure in developing a tourist destination. The results showed that American / European and Asian tourists are sensitive to the transportation infrastructure on the island. 
Table 11. Infrastructure Marketing

\begin{tabular}{llc}
\hline No & Statements & Score \\
\hline 1 & There are many choices of restaurant with various kinds of & 427 \\
2 & dishes in Bali & 396 \\
3 & There are many shopping centers in Bali & 392 \\
4 & Bali provides a variety of accommodation options & 385 \\
5 & Living in Bali feels safe and comfortable & 214 \\
6 & Bali has a good traffics and sufficient roads & 353 \\
7 & Bali has a good tourist services & 402 \\
8 & Tourist destinations are easily accessible by various kinds of & 321 \\
& public transportations & 290 \\
9 & There are many spacious parking spaces in Bali's tourist & \\
& destinations & 241 \\
\hline
\end{tabular}

From the interview results, respondents gave the highest score for restaurant facilities compared to other supporting tourism infrastructures. In other words, most tourists really enjoy various restaurants and their culinaries. An opinion from an Australia tourist regarding Bali's infrastructure he liked the most in an interview (Jacquis, 2019), stated that: 
"really like The Food, balinese people, the weather, and the shopping centers"

Transportation infrastructures (adequate and quality roads) both received the lowest scores of 214 and 241. This indicates that the attention given by the local government for transportation infrastructure is inadequate. In order to maintain the sustainability of Bali's tourism, the construction of adequate road infrastructure to reduce congestion should be given a priority in the development planning, both at the province and regency levels.

Tourists complaints regarding transportation infrastructures can be seen from several recommendations presented in the interview with Piay (2019) from Thailand and Jacub (2019) from Germany, such recommendations are as follows:

"The roads must be improved. The government needs to improve their regulations especially regarding cleanliness and roads. You need to keep the beaches clean and the traffic jam needs to be fixed. The traffic is so crowded. Bali needs to fix it."
Another complaint that disturbs foreign tourist vacation the most, obtained from the interviews with respondents regarding Bali's tourism objects and public places in Bali, is related to cleanliness. This must receive urgent attention from the government and related agencies as well as public awareness to keep the environment clean. Recommendations related to cleanliness were made by Yuka (2019) from Japan and Sally (2019) from England in their interviews :

"Sunsets and sunrises in Bali are great! But don't forget to clean the beach, cleanliness regulation should be created, because the people pay less attention on cleanliness, cleanliness needs to be improved and serious regulations must be created, please keep Bali clean, improve cleanliness and traffic management"

3. The Influence of Attraction Marketing on the Interest of Foreign Tourists to Revisit Bali

Attraction is an important reason for tourists, investors, and capital to enter a specific region. There are a lot of components of 
tourism travel, for example: transportation and accommodation are demands that are generated from the needs of consumers to enjoy what a destination has to offer, either in the sense of something to do or to see. The attractiveness of Balinese tourism objects is divided into artificial attraction and natural attraction.

Figure 1. Attraction Marketing

\begin{tabular}{|l|c|c|}
\hline $\begin{array}{l}\text { NATURAL } \\
\text { ATTRACTIONS }\end{array}$ & PLACES & \\
\hline & River, Cave & Beach \\
\hline $\begin{array}{l}\text { ARTIFICIAL } \\
\text { ATTRACTIONS }\end{array}$ & Monuments and & $\begin{array}{c}\text { Local } \\
\text { Festivals }\end{array}$ \\
\hline
\end{tabular}

The results indicate that Attraction is the reason for tourists, atraction marketing has a positive investors and capital to enter a and significant effect on the interest particular place (Kuncoro, 2014). of foreign tourists to revisit Bali.

\section{Table 12. Attraction Marketing}

\begin{tabular}{llc}
\hline No & Statements & Score \\
\hline & Artificial Attractions & \\
\hline 1 & Bali has good museums. & 352 \\
2 & Bali has good monuments. & 388 \\
3 & There are many beautiful large statues in Bali. & 433
\end{tabular}




\begin{tabular}{lll}
4 & Bali has beautiful zoos & 368 \\
5 & Bali has attractive water sports venues (rafting, canoing, etc) & 430 \\
6 & Bali provides many relaxation and fitness facilities (Spa) & 434 \\
7 & Bali has many amazing places for trekking and camping & 401 \\
8 & Bali has an Enchanting Rice Terraces & 425 \\
\hline 9 & Natural Attractions & 465 \\
10 & Bali has beautiful beaches. & 420 \\
11 & Bali has beautiful mountains. & 400 \\
12 & Bali has beautiful lakes. & 386 \\
13 & Bali has fascinating caves. & 479 \\
\hline
\end{tabular}

Source: Data processed, 2019

The beautiful beaches with their sunsets and sunrises received the highest score, which indicates that this natural attraction is still the favorite among foreign tourists visiting Bali. Bali has a beach lines that are famous worldwide including; Kuta, Legian, Sanur, Nusadua, Pandawa, Canggu, Candidasa, Lovina, Tulamben, Amed, Virgin Beach, Tanah Lot, Kedungu, Soka and Medewi Beaches.

The high interest of tourists regarding beautiful beaches can be seen from several comments made in the interviews with Robert (2019) from Belgium and Michael (2019) from Scotland, as follows:
"Beaches and surfing are very cool, Recomended places to visit is Tanah lot temple, the vegan and vegetarian food options, visiting the beaches and scuba diving as well as enjoying the night life in places like Single Fin and Potato Head. The sunset and sunrise on the beaches are unforgettable"

For artificial attractions, foreign tourist respondents favor the beauty of the large statues in Bali Province the most. Bali has a unique sculpture art that does not exist in other regions in Indonesia. Almost every corner of an area, in fact almost every crossroads are decorated with large statues uniquely made by Balinese artists. This makes Bali unique and attracts the attention and interest of tourists to visit Bali. 
The tourist interests regarding these large and beautiful statues are expressed in the interviews with Robert (2019) from Belgium and Michael (2019) from Scotland, as follows:

"the most amazing, memorable and interesting place is the GWK Statue."

\section{The Influence of People} Marketing on the Interest Foreign Tourists to Revisit Bali

This research found that people marketing has a positive and significant effect on the interest of foreign tourists to revisit Bali. The attitudes, competence and openness of the people, as well as the good governance by the local government influence tourists to visit Bali. This is in line with the research conducted by Johan (2016) in form of a comparative study regarding vacation experiences of senior tourists which stated that senior tourists really appreciate cultural experiences, competitive prices and the hospitality of the people.

Tabel 13. People Marketing

\begin{tabular}{lll}
\hline No & Statements & Score \\
\hline 1 & $\begin{array}{l}\text { The Balinese people and Balinese tourism professionals are } \\
\text { friendly and trusthworthy }\end{array}$ & 423 \\
2 & Every tourism workers in Bali has a good quality and skills & 382 \\
3 & Bali government policies for tourism sector can be trusted & 371 \\
4 & The Balinese are very open to every tourists who come to Bali & 434 \\
\hline
\end{tabular}

Source: Data processed, 2019

From the scores obtained from respondents, it can be seen that the openness, friendliness and honesty of the people and the professionalism of the tourism professionals are the most important factors influencing tourists to return to Bali. As stated by respondents in the interview with
Marie and Scott (2019) from Germany:

"The people are very kind, really impressed by the hospitality of the people. I like the people, their kindness, and their hospitality"

Jhingan (2012) stated that sometimes the people's decision to visit or invest is based on the 
openness of the people that are not business-averse. The hospitality, professionalism and the quality of Bali tourism professionals are the main drivers behind tourist visits to Bali.

\section{d. The Most Influential Factor on the Interest of Foreign Tourists to Revisit Bali}

People marketing is the single most dominant independent variable influencing the interest of foreign tourists to revisit Bali, as seen from the highest beta coefficient (0.299) compared to the betas of other independent variables. Friendliness, honesty, openness of the community, professionalism of the workforce and the government of Bali are the factors that mostly influence the interest of foreign tourists to revisit to Bali. Nevertheless, all four factors above

\section{REFERENCES}

Antara, Made, (2016) Kebutuhan Investasi Sektor Basis Dan Non Basis Dalam Perekonomian Bali, media.neliti.com

Anuar, Ahmad nazrin Aris, Ahmad, Habibah, Jusoh, Hamzah, Hussain, Mohd Yusof. 2012. The Roles of Tourism Towards Deelopment of has become the attractiveness of Bali's tourism that can not be found elsewhere.

\section{CONCLUSION}

Image, infrastructure marketing, attraction marketing and people marketing, all have positive and significant effects on the interest of foreign tourists to revisit Bali. People marketing is the most dominant independent variable influencing the interest of foreign tourists to return to Bali. Identification of variables that can foster the interest of tourists to revisit Bali is expected to provide a picture to various related parties and can serve as a reference in decision making. Policy formulation by related agencies can be aligned with the findings in this research so that its implementation can be

$$
\text { conducted optimally. }
$$

Tourist Friendly Destination Concept. Asian Social Science, 8(6), pp:146-155 BPS Bali, 2016, Bali Dalam Angka.

Bertan, Serkan, (2013) Visitors
Perception Of A Tourism
Destination: the case Of
Pamukale. Tourismos an
International Multidiciplinary
Journal of Tourism, 8 (1) hal.
115-132.


Blazeska, Daliborka,(2018) The Influence of tourist Infrastructure on the Tourist Satisfaction in Orhid, UTMS Journal of Economics 9 (1); 85-93

Chiu, Wheisheng (2016), The Influence of Destination Image and Tourist satisfaction on Tourist Loyalty: A Case Study of Chinese Tourist in Korea, International Journal of Culture Tourism and Hospitality Research 10(2): 223-234.

Dinas Pariwisata Provinsi Bali, 2017, Statistik Pariwisata Bali

Dinas Pariwisata DKI Jakarta, 2017, Statistik Pariwisata Jakarta

Dinas Pariwisata Provinsi Riau, 2017, Statistik Pariwisata Riau

Hasan, Ali, 2010 marketing dari mulut ke mulut. Yogyakarta: Media Pressindo

Jhingan, M.L. 2000, Ekonomi Pembangunan dan

Perencanaan, terjemahan D. Guritno, Ed.1Cet. 8, PT. RajaGrafindo Persada, Jakarta.

Johan maria, 2016, Benchmarking Holiday Experience: The Case Of Senior Tourists, Benchmarking: An international Journal 23 (7), 1860-1875.

Khadaroo, Jameel (2007), Transport Infrastructure and tourism development, Annals of Tourism Reasearch 34 (4); 1021-1032

Kuncoro, Mudrajat,2014, Otonomi Daerah Menuju Era Baru Pembangunan Daerah,Erlangga Yogyakarta

Nasrullah, Rulli (2015), Media Sosial: Prosedur, Tren dan Etika. BandungSimbiosa Rekatama Media
Nuraini, Belinda Sofia, 2014, Analisis ator-fator Yang Mempengaruh Minat Kunjung Ulang Wisatawan Museum Ranggawarsita Semarang, jurnal Bisns Strategi 23 (1)

Powell, Hickman, 1936, Bali: The Last Paradise, Dodd, Mead \& Company, Amerika.

Putri, Novia Sri, dkk,2014, Persepsi Wsatawan Tentang Destinasi Wisata Taman Margasatwa Dan Budaya Kinantan Bukittinggi, skripsi Fakultas Teknik Pariwisata Uniersitas Negeri Padang.

Rajesh, R, 2013, Impact Of Tourist Perceptions, Destination Image and Tourist Satisfaction On Destination Loyalty; A conseptual Model.Pasos. Revista De Turismo y Patrimonio cultural journal 11(3) hal.67-78.

Sukirno Sadono, 2006, Ekonomi Pembangunan Proses, Masalah, dan Dasar Kebijakan, Kencana Prenada Media Group, Jakarta

Suyana Utama, 2009, Aplikasi Kuantitatif, Ed. 3, Fakultas Ekonomi dan Bisnis, Denpasar

Tourismos an International Multidisciplinary Journal of Tourism, 8 (1) hal. 115-132. Dinas Pariwisata Provinsi Bali, 2017, Statistik Pariwisata Bali

Undang-Undang Republik Indonesia No 10 Tahun 2009 Tentang Kepariwisataan Januari 2009. Lembaran Negara Republik Indonesia Tahun 2009. Jakarta

Widagdo, Kurniawan Gilang, 2017, Daya Tarik Ekowisata dan 
Minat Berkunjung Wisatawan, Jurnal Bisnis dan manajemen Fakultas

Ekonom

Universitas sahid Jakarta https;//tribunnews.com diunduh 9 februari 2019,12.29

https;//merahputih.com diunduh 9 februari 2019,15.00

Yoeti, Oka A. 2001, Tours and Travel Management, Edisi 6, PT Pradnya Paramita, Jakarta. 